\title{
Aktivitas Antimutagen Isoflavon Glikosida Hasil Transglikosilasi Enzimatik CGT-ase Bacillus macerans
}

\author{
Antimutagen Activity of Synthesized Isoflavone Glycoside by Enzymatically \\ Transglycosylation
}

\author{
Joko Sulistyo* dan Yati Sudaryati Soeka
}

Bidang Mikrobiologi Pusat Penelitian Biologi - LIPI, Jl. Raya Bogor-Jakarta Km. 46, Cibinong 16911

E-mail:josulisty@yahoo.com *Penulis untuk korespondensi

\begin{abstract}
It has been known that isoflavone have biological activities such as antioxidant, antibacteria, antimutagenesis, and anticancer. Isoflavone aglycone uses such as genistein, daidzein and glycitein are limited since they are unstable and uneasily to dissolve in water. Through enzymatic transglycosylation reaction, its stability and solubility could be improved. In this study, genistin (isoflavone glycoside) was synthesized from genistein (isoflavone aglycone) by application of transfer reaction using enzyme cyclodextrin glucanotransferase (CGT-ase) of Bacillus macerans. Identification of the product was determined by TLC with methanol: chloroform (1:3, v:v) as eluent. Rf value 0.75 of the synthesized product was close to the $R f$ value standard of authentic genistin glycoside. The synthesized genistin was furthermore assayed to determine its antimutagenesis activity according to the Ames methode on E. minimal glucose media had been precultured with a mutant strain of Salmonella thypimurium TA98. The tested bacterial strain was induced with aflatoksin $B_{1}$ as mutagen which had been activated with a lever homogenate. The result showed that the solubility and some biological properties of the synthesized genistin were improved higher than that of genistein, while it was found to be lower than that of the commercial genistin.
\end{abstract}

Key words: CGT-ase, Bacillus macerans, transglycosylation, genistin, antimutagenesis

Diterima: 18 April 2008, disetujui: 12 November 2008

\section{Pendahuluan}

Indonesia merupakan negara tropis yang kaya akan sumber daya alam. Tanahnya yang subur menjadikan berbagai tanaman dapat tumbuh, termasuk tanaman leguminosa seperti kedelai. Produk pangan dengan bahan dasar kedelai sangat populer di masyarakat karena selain harganya murah bahan pangan tersebut mempunyai kandungan nutrisi esensial yang tinggi. Produk pangan dengan bahan dasar kedelai seperti tempe, tahu, dan susu sangat populer di masyarakat. Harganya yang murah, nutrisi esensial yang tinggi dan kandungan senyawa aktif (isoflavon) yang dimiliki, menyebabkan kedelai banyak mengundang perhatian untuk diteliti. Kedelai kering mengandung 35\% Protein, 35\% hidrat arang, $20 \%$ lemak, $8 \%$ air, dan 2\% mineral (Direktorat Gizi Depkes RI, 1972).

Saat ini pemanfaatan senyawa isoflavon dari kedelai banyak menarik perhatian karena khasiatnya bagi kesehatan. Telah diketahui beberapa senyawa polifenol termasuk isoflavon memiliki aktivitas antibakteri, antioksidan, antimelanogenesis, antimutagen dan antikanker (Funayama et al., 1994; Klein, 1998; Mulya, 1999).

Berdasarkan survei oleh Tsuzuki (1998) rendahnya angka kematian di Jepang akibat jantung koroner, kanker payudara, kanker rahim, dan aterosklerosis dipengaruhi oleh 
tingginya tingkat konsumsi makanan dari kedelai seperti tahu, natto, dan susu. Menurutnya, Isoflavon aglikon yang ada pada kedelai seperti genistein, daidzein, dan glycitein merupakan senyawa nonsteroid yang mempunyai aktivitas biologis seperti fitoestrogen, antioksidan, dan antimutagen. Namun sayangnya, senyawa ini sangat sensitif terhadap sinar matahari, kurang larut dalam air, dan mudah mengalami perubahan kimia seperti proses oksidasi dan reduksi.

Mengingat potensi senyawa isoflavon yang cukup besar maka dirasakan perlu adanya upaya untuk meningkatkan kestabilan dan sifat kelarutannya. Peningkatan kestabilan dan kelarutannya dapat dilakukan dengan cara mensintesis isoflavon aglikon menjadi bentuk glikosida melalui reaksi transglikosilasi dengan bantuan enzim yang memiliki aktivitas transfer seperti siklodekstrin glukanotransferase (CGTase) (Kometani et al., 1994). Dalam penelitian ini metode enzimatik menjadi pilihan karena cukup efisien, mudah dilakukan, prosesnya bersifat selektif dan spesifik. Pembentukan produk campuran dengan konformasi $\alpha$ - atau $\beta$-glikosida dan hasil samping yang tidak diinginkan yang terjadi dalam reaksi kimia dapat dihindari (Nilsson, 1988). Selain itu sintesis senyawa secara enzimatik cukup ekonomis dan ramah lingkungan karena menggunakan bahan-bahan yang alamiah dan tidak menimbulkan masalah pencemaran.

Hasil penelitian diharapkan dapat bermanfaat untuk bidang kesehatan, terutama untuk memperoleh senyawa-senyawa antimutagen yang lebih stabil dan mempunyai aktivitas biologis yang lebih baik. Dengan demikian penggunaan isoflavon glikosida sebagai obat atau suplemen yang diperlukan dalam industri pangan, kosmetik, dan farmasi dapat lebih dioptimalkan.

Penelitian ini bertujuan untuk mensintesis isoflavon glikosida dan menguji produk hasil reaksi transfer sebagai senyawa antimutagenesis, menggunakan metode Ames, melalui pemanfaatan aktivitas enzim siklodekstrin glukanotransferase (CGT-ase) yang berasal dari biakan Bacillus macerans.

\section{Metode Penelitian}

\section{Enzim}

Enzim yang digunakan adalah Enzim siklodekstrin glukanotranferase (CGT-ase) dari Bacillus macerans. Genistein dari Wako Pure Chemical Industries, genistin dari Fujicco Chemical Japan, pati terlarut dari Merck KgaA, 64271 Darmstadt Germany, dan aflatoksin $\mathrm{B}_{1}$ dari Sigma Chemical Company.

\section{Uji aktivitas transfer}

Campuran reaksi sebanyak $1 \mathrm{ml}$ yang terdiri dari $0,5 \mathrm{ml}$ bufer fosfat $0,01 \mathrm{M} \mathrm{pH} 6,5$ (mengandung 5\% pati terlarut dan $0,5 \%$ genistein) direaksikan dengan $0,5 \mathrm{ml}$ enzim CGT-ase, larutan lalu diinkubasi pada suhu $40^{\circ} \mathrm{C}$ selama 24 jam. Produk transfer yang dihasilkan diuji dengan KLT dan dielusi dengan larutan pengembang metanol: kloroform (1:3 v:v). Deteksi senyawa dilakukan dengan penyinaran UV pada panjang gelombang $254 \mathrm{~nm}$. Standar yang digunakan merupakan campuran yang terdiri dari genistin, genistein (Funayama et al., 1994).

\section{Pemisahan dan pemurnian produk transfer}

Pemurnian komponen dilakukan dengan menggunakan KLT preparatif silikagel. Penyepotan sampel dilakukan dalam bentuk pita. Setelah itu sampel dielusi dengan metanol: kloroform $(1: 3 \mathrm{v}: \mathrm{v})$.

CGT-ase diperoleh dari Bacillus macerans yang telah dikulturkan sebelumnya pada media nutrien agar (NA). Biakan diinokulasikan ke dalam media produksi mengandung $2 \%$ pati terlarut; $5 \%$ pepton; $0,1 \%$ $\mathrm{K}_{2} \mathrm{HPO}_{4} ; 0,05 \% \mathrm{NaCl} ; 0,05 \% \mathrm{MgSO}_{4} ; 0,01 \%$ $\mathrm{FeSO}_{4} ; 0,0001 \% \mathrm{ZnSO}_{4} ; 0,0001 \% \mathrm{MnSO}_{4}$; dan $0,0001 \% \mathrm{CaSO}_{4}$ dalam bufer fosfat $0,01 \mathrm{M} \mathrm{pH}$ 6,5 . Media digoyang selama 5 hari pada suhu $25^{\circ} \mathrm{C}$ dan selanjutnya disentrifus pada kecepatan $10.000 \mathrm{rpm}$, suhu $4^{\circ} \mathrm{C}$ selama 15 menit. Supernatan yang diperoleh merupakan sumber enzim CGT-ase (Sulistyo dan Soeka, 1999).

Produk transfer yang diperoleh diidentifikasi dengan sinar UV pada $\lambda 254 \mathrm{~nm}$ kemudian dikerok lalu diekstraksi dengan 20 $\mathrm{ml}$ etanol 80\%. Ekstraksi dilakukan sebanyak 5 
kali pengulangan. Larutan disaring dengan kertas saring Whatman no. 1. Filtrat yang diperoleh kemudian diuji lagi pada KLT analitik.

\section{Pembuatan homogenat hati}

Sebanyak $10 \mathrm{~g}$ hati ayam, ditambah 50 $\mathrm{ml}$ bufer fosfat $0,01 \mathrm{M} \mathrm{pH} \mathrm{6,5} \mathrm{lalu} \mathrm{dihaluskan.}$ Setelah itu campuran tersebut disentrifuse pada $17.500 \mathrm{rpm}$ selama 15 menit pada suhu $4^{\circ} \mathrm{C}$. Supernatan yang diperoleh kemudian disaring dengan kertas saring Whatman nomor 41 lalu dimasukkan ke dalam botol steril.

\section{Uji aktivitas antimutagenesis}

Bioassai antimutagenesis dilakukan dengan menggunakan modifikasi metode Ames et al., (1975). Uji dilakukan pada media E. minimal glukosa yang mengandung $2 \%$ glukosa dan $1,5 \%$ agar dalam larutan stok E. minimal glucose yang telah diencerkan 50 kali. Sebanyak $30 \mathrm{ml}$ campuran tersebut dimasukkan ke dalam cawan petri steril hingga memadat. Sementara itu dibuat campuran reaksi yang terdiri dari 2,0 $\mathrm{ml}$ top agar; $0,1 \mathrm{ml} S$. Thyphimurium TA98; 0,05 mg/L mutagen $\mathrm{AFB}_{1} ; 0,05 \mathrm{ml}$ homogenat hati; dan $0,2 \mathrm{ml}$ larutan isoflavon glikosida $(100 \mathrm{mg} / \mathrm{L}, 200$ $\mathrm{mg} / \mathrm{L})$ dalam tabung reaksi yang steril. Campuran reaksi itu kemudian dimasukkan ke dalam cawan petri yang telah berisi padatan E. minimal glucose. Setelah itu media diinkubasi pada suhu $37^{\circ} \mathrm{C}$ selama 48 jam di ruang gelap. Kontrol berupa larutan penguji yang mengandung larutan top agar dan Salmonella thyphimurium tanpa mutagen.

\section{Penentuan kadar gula total}

Sebanyak $1 \mathrm{ml}$ sampel direaksikan dengan $5 \mathrm{ml} \mathrm{H}_{2} \mathrm{SO}_{4}$ p.a ditambah $1 \mathrm{ml}$ fenol 5\%. Campuran reaksi tersebut kemudian didinginkan pada air yang mengalir. Setelah itu absorbans larutan diukur dengan spektrofotometer UV-VIS Perkin Elmer Lambda $3 \mathrm{~b}$ pada $\lambda 480 \mathrm{~nm}$. Standar yang digunakan adalah genistin.

\section{Hasil dan Pembahasan}

\section{CGT-ase dan aktivitas transfer}

Enzim CGT-ase yang dihasilkan oleh $B$. macerans tergolong sabagai enzim ekstraseluler yang disekresikan mikroorganisme ke luar sel guna menghidrolisis senyawa polimer organik menjadi senyawa yang lebih sederhana sebagai sumber nutrisi bagi kelangsungan hidup mikroorganisme tersebut.

Penambahan pati terlarut pada media produksi enzim dimaksudkan untuk menginduksi mikroorganisme agar dapat mensekresikan enzim yang diinginkan, sehingga enzim yang dihasilkan mempunyai aktivitas yang tinggi terhadap substrat pati tersebut, baik dalam aktivitas hidrolitik maupun dalam aktivitas transfernya.

Selain CGT-ase, enzim lain yang mungkin dihasilkan oleh $B$. macerans adalah $\alpha$-amilase. Melalui pengujian aktivitas transfer pada KLT, ke-2 enzim ini dapat dibedakan. Enzim $\alpha$-amilase hanya mempunyai kemampuan menghidrolisis pati saja menjadi glukosa dan maltosa. Sedangkan enzim CGTase disamping memiliki kemampuan menghidrolisis pati, juga mempunyai kemampuan melakukan aktivitas transglikosilasi yaitu melakukan reaksi pemindahan gugus glukosil dari donor (hasil hidrolisis pati) ke akseptor yang sesuai (senyawaan fenol seperti pirokatekol, resolsinol maupun genistein) secara intermolekuler.

Kemampuan aktivitas hidrolitik CGT-ase dapat diketahui melalui pengujian aktivitas enzim yaitu menggunakan substrat pati terlarut yang direaksikan dengan larutan $\mathrm{KI}$ dalam $\mathrm{I}_{2}$ sehingga terbentuk larutan berwarna biru. Intensitas warna yang terbentuk berbanding lurus dengan banyaknya pati yang tidak terhidrolisis. Semakin banyak pati yang terhidrolisis maka warna biru akan semakin pudar. Satu unit enzim didefinisikan sebagai sejumlah enzim yang dapat menyebabkan penurunan unit absorbans sebanyak 0,5 pada panjang gelombang $660 \mathrm{~nm}$ (Funayama et al., 1993)

Berdasarkan hasil pengujian aktivitas enzim, CGT-ase dari B. macerans mempunyai aktivitas optimum pada suhu $40^{\circ} \mathrm{C}$ sebesar 
2,936 unit/menit/ml dan pada $\mathrm{pH}$ 6,0 sebesar 11,613 unit/menit/ml (Handayani et al., 2002).

Hasil analisis KLT pada Gambar 1. menunjukkan bahwa enzim CGT-ase yang diekstrak dari $B$. macerans mempunyai kemampuan untuk melaksanakan reaksi transfer terhadap gugus glukosil yang dihasilkan dari hidrolisis pati (donor) ke akseptor genistein. Dengan kata lain genistin (isoflavon glikosida) dapat disintesis secara bioproses dari akseptornya genistein. Berdasarkan penampakkan spot pada plat KLT, dapat ditentukan nilai Rf standar yang digunakan sebagai pembanding dan nilai $\mathrm{Rf}$ produk. Dari hasil analisis diperoleh nilai $\mathrm{Rf}$ produk transfer sebesar 0,75 sesuai dengan nilai Rf standar. Nilai Rf ini merupakan perbandingan antara jarak tempuh spot produk dengan jarak tempuh larutan pengembang yang digunakan.

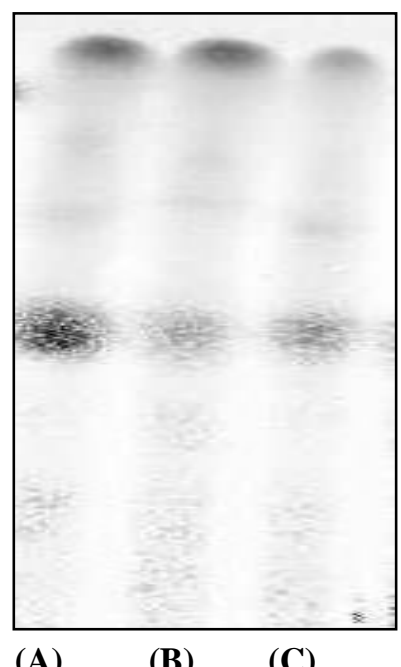

(A)

(B)

(C)

Gambar 1. Kromatogram hasil uji aktivitas transfer CGT-ase menggunakan isoflavon genestein sebagai akspetor (C) dibandingkan standar (A dan B).

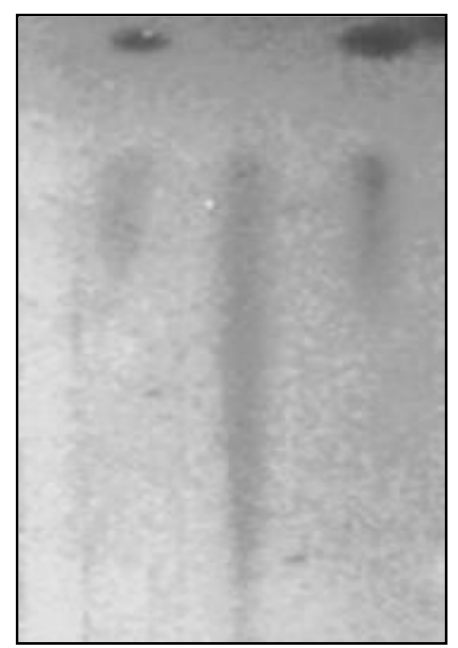
(A)
(B)
(C)

Gambar 2. Kromatogram hasil pemurniaan isoflavon glikosida (genistin) dengan teknik kromatografi preparatif. Larutan standar (A dan C) dan sampel (B). 
Pendeteksian produk transfer genistin dilakukan dengan penyinaran ultra violet pada $\lambda 254 \mathrm{~nm}$ disebabkan identifikasi untuk senyawa isoflavon sangat sulit dilakukan karena tidak ada pereaksi warna yang khas untuk mendeteksinya. Berdasarkan hasil percobaan baik genistein maupun genistin apabila disemprot dengan larutan pembangkit $\mathrm{H}_{2} \mathrm{SO}_{4} 20 \%$ dalam metanol maka akan memberikan spot berupa bercak lembayung yang semakin lama semakin memudar. Deteksi komponen dengan sinar UV dimungkinkan karena adanya cincin aromatik pada senyawa tersebut. Menurut Suradikusumah (1989) senyawa fenol memiliki cincin aromatik yang dapat menunjukkan penyerapan pada daerah UV dengan fluoresensi dari senyawa yang bersangkutan.

\section{Pemisahan dan pemurniaan isoflavon glikosida}

Produk transfer genistin dimurnikan dari akseptor genistein, dengan pertimbangan bahwa kedua senyawa tersebut sama-sama memiliki aktivitas antimutagenesis. Isoflavon aglikon genistein selain sukar larut dalam air, senyawa tersebut juga tidak stabil, mudah teroksidasi baik di udara terbuka maupun oleh reaksi-reaksi kimia. Hal ini dimungkinkan terjadi karena banyaknya gugus hidroksil yang aktif pada genistein.

Melalui reaksi transglikosilasi, salah satu gugus aktif hidroksil genistein digabungkan dengan gugus glukosil secara selektif dan spesifik oleh CGT-ase dan diharapkan genistin yang diperoleh sebagai produk transfer mempunyai kestabilan yang lebih tinggi begitu pula dengan daya solutbilitasnya dalam air. Pada Gambar 2 dapat dilihat kromatogram produk transfer genistin yang telah dimurnikan. Dari hasil penentuan kadar gula Dubois didapatkan rendemen produk transfer sebesar $51,76 \%$. Produk yang diperoleh tersebut akan diuji aktivitasnya sebagai senyawa antimutagen. Adapun struktur kimia produk transfer isoflavon glikosida genistin yang dihasilkan secara bioproses, menggunakan enzim siklodekstrin glukanotransferase dari $B$. macerans dapat dilihat pada Gambar 3 (Sulistyo et al., 2000).

\section{Uji aktivitas antimutagenesis}

Uji antimutagenesis berdasarkan metode Ames merupakan metode yang cukup ekonomis dan dapat dengan cepat memberikan informasi yang diperlukan mengenai bahan bahan kimia yang bersifat karsinogenik dan mutagenik. Pengujian dilakukan pada cawan petri menggunakan beberapa rancangan khusus misalnya penggunaaan $S$. thyphimurium. Bakteri ini dipilih karena umum dijumpai, tidak dapat hidup tanpa asam amino histidin yang cukup, sangat sensitif terhadap senyawa karsinogen dan mutagen semacam Aflatoksin $\mathrm{B}_{1}$.

Hasil pengujian sebagaimana pada Gambar 4 menunjukkan bahwa pada media (1) tanpa mutagen aflatoksin $\mathrm{B}_{1}, S$. thyphimurium tidak tumbuh atau mutasi tidak terjadi sebab pertumbuhan koloni sama dengan nol. Hal tersebut kemungkinan dipengaruhi oleh komposisi media yang miskin nutrisi, terutama asam amino histidin yang diperlukan untuk kelangsungan hidup $S$. thyphimurium tidak mencukupi, sehingga mikroorganisme tersebut mati dan mutasi secara spontan tidak terjadi. Menurut Lehniger (1994) S. thyphimurium tidak dapat hidup pada kondisi yang kurang asam amino histidin. Hal serupa terjadi pula pada media (2) yang diberi mutagen $\mathrm{AFB}_{1}$ tanpa penambahan homogenat hati. Pada kondisi ini mutasi tidak terjadi diduga karena berjalannya sistem repair dari sel normal. Saat sel mengalami gangguan pada fungsi normalnya, maka sel akan mati sebelum terjadi mutasi. Menurut Uraguchi \& Yamazaki (1978), sel-sel normal yang dimasuki mutagen atau senyawa karsinogenik akan mati dengan menjalankan sistem repairnya sehingga mutagen yang dipakai tidak efektif.

Pada media (3) yaitu media yang diberi mutagen $\mathrm{AFB}_{1}$ dan ditambah dengan homogenat hati, $S$. thyphimurium mengalami mutasi. Proses mutasi ditandai oleh pertumbuhan mutan yang pesat. Mutan yang dihasilkan pada media (3) diduga karena adanya homogenat hati dapat menyediakan enzim yang bisa mengaktifkan mutagen $\mathrm{AFB}_{1}$. Menurut Lehninger (1994) homogenat hati dapat menyediakan enzim retikulum endoplasmik yang mampu mengkatalisis reaksi 
hidroksilasi atau mengubah banyak senyawa organik asing yang tidak atau kurang aktif menjadi bentuk akhir yang aktif.

Penggabungan secara langsung homogenat hati dengan mutagen $\mathrm{AFB}_{1}$ merupakan aspek penting dalam uji secara invitro, karena pengujian dilakukan pada berbagai macam senyawa karsinogenik dan mutagenik yang memerlukan pengaktifan metabolit yang dapat disediakan oleh homogenat hati (Uraguchi dan Yamazaki, 1978).

Ada dua pendekatan tentang analisis toksikologi mutagen aflatoksin, yaitu: analisis sekuen pada fungsi hati dan analisis sekuen pada proses biotransformasi aflatoksin pada organ hati yang berhubungan dengan sifat toksiknya. Melalui pendekatan kedua Patteron et al., (1973) dalam Uraguchi dan Yamazaki (1978) menyelidiki tentang terjadinya proses biotransformasi $\mathrm{AFB}_{1}$ dalam sel organisme, bahwa penggabungan atau melekatnya $\mathrm{AFB}_{1}$ pada inti DNA, menyebabkan inti menjadi rusak dan sintesis RNA menjadi terhambat. Selain itu adanya mutagen aflatoksin dalam sel dapat menyebabkan fungsi dan sistem retikulum endoplasma terganggu misalnya terjadi degradasi polisomal dan pelepasan ribosom dari organel tersebut.

Aflatoksin $\mathrm{B}_{1}$ adalah senyawa mutagen yang bersifat aktif. Secara intraseluler aflatoksin $\mathrm{B}_{1}$ direduksi menjadi aflatoksikol secara reversibel. Aflatoksin $\mathrm{B}_{1}$ diubah menjadi bentuk aktif apabila enzim mikrosomal oksigenase melakukan aktivitas katalitik mengubah $\mathrm{AFB}_{1}$ menjadi metabolit yang polar dan aflatoksin epoksida. Metabolit polar dapat dihilangkan dari sel hati melalui mekanisme perbaikan yang dilakukan oleh enzim repair. Namun epoksida merupakan cikal bakal dari toksisitas senyawa aflatoksin. Senyawa epoksida melakukan aktivitas hidrolitik dan menghasilkan produk berupa aflatoksin $\mathrm{B}_{2}$ $\left(\mathrm{AFB}_{2}\right)$ yaitu senyawa metabolik yang tidak stabil dan dapat berubah menjadi senyawa fenolat pada kondisi fisiologis $\mathrm{pH} 7,4$. Bentuk fenolat $\mathrm{AFB}_{2}$ akan bereaksi dengan asam nukleat dan protein membentuk senyawa mutagen. Sifat mutagenesis ini akan diturunkan pada generasi selanjutnya dan bersifat permanent, karena sifat itulah, senyawa aflatoksin $\mathrm{B}_{1}$ dikelompokkan sebagai senyawa mutagenik.

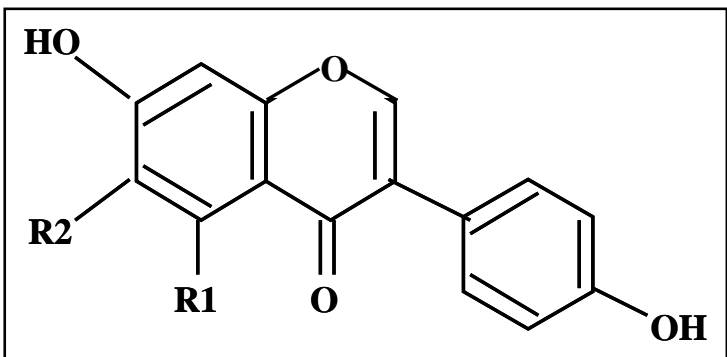

Gambar 3. Isoflavon glikosida genistin.

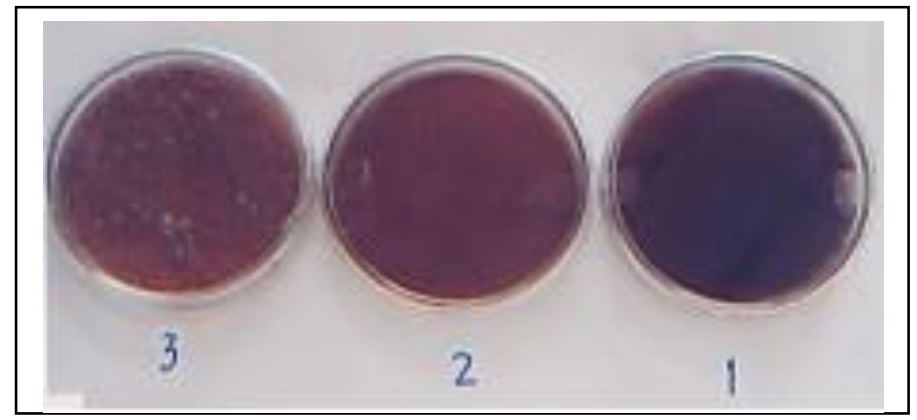

Gambar 4. Uji mutagenesis mutan S. thyphimurium.

Keterangan: (1) kontrol, (2) Media dengan mutagen $\mathrm{AFB}_{1}$ tanpa homogenat hati, (3) Media dengan mutagen $\mathrm{AFB}_{1}$ yang ditambah dengan homogenat hati (terlihat pertumbuhan koloni). 
Berdasarkan hasil pengujian antimutagenesis (Tabel 1) diperoleh hasil bahwa pada konsentrasi $100 \mathrm{mg} / \mathrm{L}$ genistein, genistin sintesis dan genistin komersial secara berturut-turut mempunyai aktivitas sebesar 51,31; 62,32; dan 67,49\%. Pada Gambar 7 terlihat bahwa ke-3 senyawa isoflavon memiliki tingkat aktivitas antimutagenesis yang berbeda. Aktivitas antimutagen genistin hasil sintesis enzimatik lebih tinggi dibandingkan genistein namun lebih rendah dibandingkan produk genistin komersial.

Peningkatan konsentrasi isoflavon hingga $200 \mathrm{mg} / \mathrm{L}$ menunjukkan bahwa aktivitas antimutagenesis ketiga senyawa isoflavon tersebut meningkat seiring peningkatan konsentrasi yang digunakan, yaitu menjadi sebesar $65,39 \%$ untuk genistein, $73,03 \%$ untuk genistin hasil sintesis enzimatik dan $83,82 \%$ untuk genistin komersial.

Hal tersebut mungkin terjadi karena dipengaruhi oleh ketidakstabilan genistein. Strukturnya mudah berubah akibat oksidasi oleh cahaya diudara terbuka sehingga sifat aktifnya berkurang. Akibatnya genistein kurang efektif dalam menghentikan mutasi sel. Menurut Kitao et al., (1993) senyawa polifenol bersifat tidak stabil terhadap pengaruh oksidasi, cahaya, dan perubahan kimia akibat banyaknya gugus hidroksil yang aktif sehingga apabila teroksidasi maka strukturnya akan berubah dan fungsinya sebagai bahan aktif akan menurun, bahkan hilang.

Melalui proses tranglikosilasi oleh CGTase dari Bacillus macerans salah satu gugus hidroksil yang aktif dari akseptor genistein (isoflavon aglikon) diikat dengan gugus glukosil. Sehingga diperoleh produk transfer berupa isoflavon glikosida yang lebih stabil dan memiliki aktivitas biologis lebih baik dibandingkan akseptornya genistein. Sulistyo et al., (1998) menyatakan bahwa enzim CGT-ase dapat dimanfaatkan dalam reaksi transglikosilasi dengan menggunakan senyawa polifenol sebagai akseptor. Meskipun genistin komersial (otentik) mempunyai aktivitas antimutagenesis tertinggi dibandingkan kedua produk lainnya, namun senyawa isoflavon glikosida hasil sintesis secara enzimatik memiliki nilai potensial yang tinggi, sehingga dapat dimanfaatkan secara optimal, terutama sebagai senyawa antimutagen dalam dunia kesehatan atau sebagai suplemen dalam produk-produk pangan, kosmetik dan lainnya.

Ada pun proses pengikatan $\mathrm{AFB}_{1}$ pada inti DNA atau RNA hati menurut Uraguchi dan Yamazaki (1978) dapat dilihat pada Gambar 8.

Tabel 1. Uji aktivitas antimutagenesis isoflavon terhadap S. typhimurium dengan mutagen $\mathrm{AFB}_{1}$.

\begin{tabular}{|c|c|c|c|c|c|c|c|c|c|}
\hline \multicolumn{10}{|c|}{ Jumlah Koloni Mutan } \\
\hline \multirow[t]{2}{*}{ Ulangan } & \multirow[t]{2}{*}{ Kontrol } & \multirow[t]{2}{*}{$\begin{array}{l}\text { Mutagen (-) } \\
\text { Homogenat }\end{array}$} & \multirow[t]{2}{*}{$\begin{array}{c}\text { Mutagen (+) } \\
\text { Homogenat }\end{array}$} & \multicolumn{2}{|c|}{ Genistein } & \multicolumn{2}{|c|}{ Genistin } & \multicolumn{2}{|c|}{$\begin{array}{c}\text { Genistin } \\
\text { Komersial }\end{array}$} \\
\hline & & & & $\begin{array}{r}100 \\
\mathrm{mg} / \mathrm{L}\end{array}$ & $\begin{array}{c}200 \\
\mathrm{mg} / \mathrm{L}\end{array}$ & $\begin{array}{c}100 \\
\mathrm{mg} / \mathrm{L}\end{array}$ & $\begin{array}{r}200 \\
\mathrm{mg} / \mathrm{L} \\
\end{array}$ & $\begin{array}{c}100 \\
\mathrm{mg} / \mathrm{L}\end{array}$ & $\begin{array}{c}200 \\
\mathrm{mg} / \mathrm{L}\end{array}$ \\
\hline 1 & 0 & 0 & 289 & 137 & 81 & 87 & 699 & 83 & 445 \\
\hline 2 & 0 & 0 & 257 & 150 & 106 & 110 & 73 & 97 & 39 \\
\hline 3 & 1 & 0 & 260 & 110 & 95 & 108 & 77 & 74 & 41 \\
\hline 4 & 0 & 0 & 277 & 123 & 91 & 95 & 66 & 81 & 43 \\
\hline 5 & 3 & 1 & 248 & 129 & 89 & 103 & 75 & 99 & 48 \\
\hline Rata-rata & 0.8 & 0.2 & 267 & 130 & 92.4 & 100.6 & 72 & 86.8 & 43.2 \\
\hline Persenta & penghar & atan mutage & $\%)$ & 51.31 & 65.79 & 62.32 & 73.03 & 67.49 & 83.82 \\
\hline
\end{tabular}




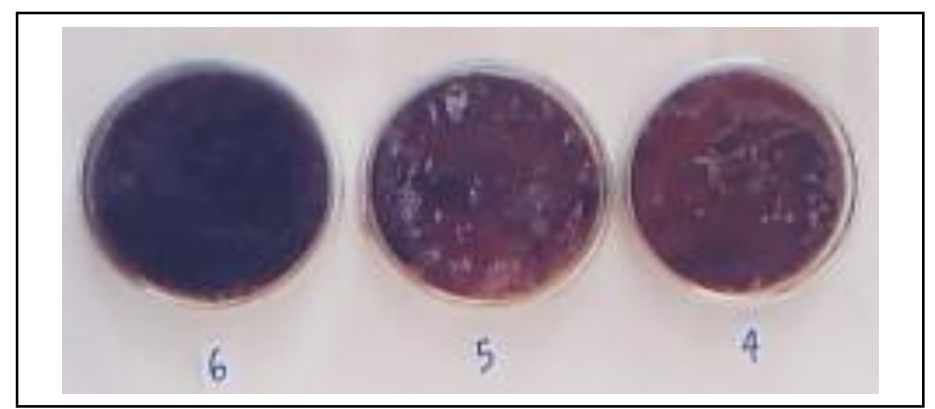

Gambar 7. Uji antimutagenesis senyawa isflavon pada konsentrasi $100 \mathrm{mg} / \mathrm{L}$ : (4) Genistein, (5) genistin sintesis, dan (6) Genistin otentik.

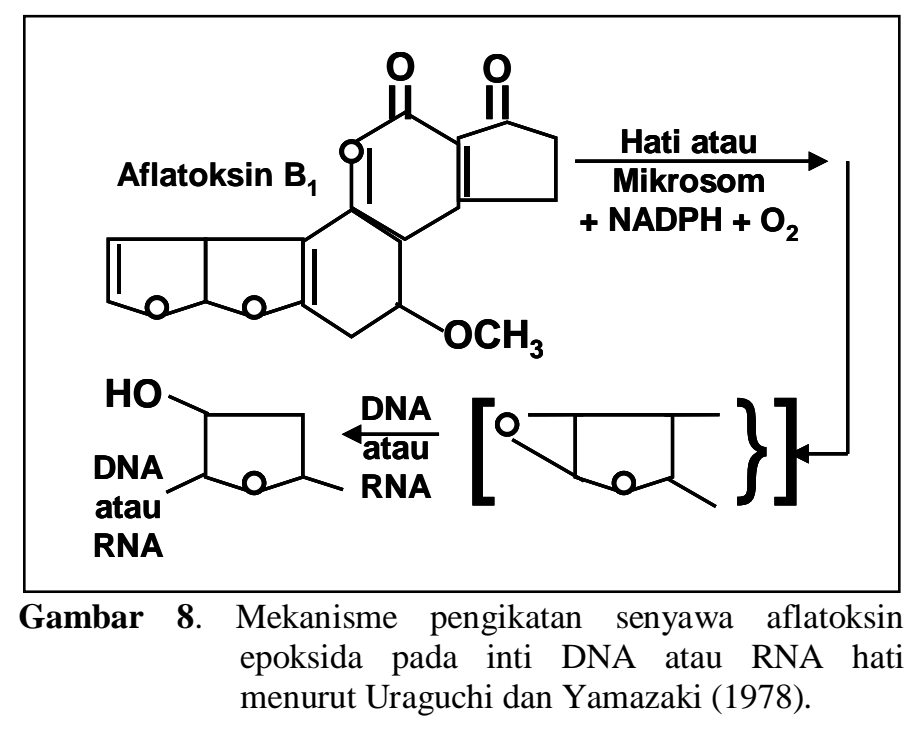

\section{Kesimpulan}

Isoflavon glikosida-genistin dapat disintesis menggunakan enzim CGT-ase dari biakan Bacillus macerans. Hasil uji antimutagenesis menunjukkan bahwa isoflavon aglikon genistein, genistin hasil sintesis dan genistin otentik pada konsentrasi $100 \mathrm{mg} / \mathrm{L}$ mempunyai aktivitas biologis sebagai antimutagen yaitu masing-masing sebesar 51,$31 ; 62,32$ dan 67,49\%. Sedangkan pada konsentrasi $200 \mathrm{mg} / \mathrm{L}$ aktivitasnya meningkat menjadi 65,39, 73,03 dan 83,82\%. Aktivitas biologis genistin hasil sintesis sebagai antimutagen menunjukkan hasil lebih tinggi dibandingkan genistein-aglikon, meskipun lebih rendah dibandingkan genistin komersial.

\section{Ucapan Terima Kasih}

Ucapan terima kasih disampaikan kepada Dwi Astuti S.Si atas ketekunannya dalam membantu pelaksanaan penelitian, sehingga penelitian dapat terlaksana dengan baik.

\section{Daftar Pustaka}

Ames, B.N., Mccann, J. and Yamasaki, E. 1975. Methods for Detecting Carcionogens and Mutagen with the Salmonella / Mammalian - Microsome Mutagenicity Test. Mutation Research. 3: 347-364.

Direktorat Gizi Departemen Kesehatan RI. 1972. Daftar Komposisi Bahan Makanan. Bharatara, Jakarta. 
Funayama, M., Arakawa, H., Nishino, T., Hirota, A., Murao, S., Takenishi, S. and Nakano, H. 1993. Enzymatic Synthesis of (+) Catechin- $\alpha-$ Glucoside and Its Effect on Tyrosinase Activity. Biosci. Biotech. Biochem. 57: 16661669.

Funayama, M., Arakawa, H., Yamamoto, R., Nishino, T., Shint, T. and Murao, S. 1994. Effect of $\alpha$ and $\beta$-arbutin on Activity of Tyrosinase from Mushroom and Mouse Melanoma. Biosci. Biotech. Biochem. 59: 143-144.

Handayani, R., Hawab, M. and Sulistyo, J. 2002. Antioxidation Activity of Polyphenol Glycosides Synthesized by Enzymatic Transglycosylation Reaction of Bacillus macerans. J. BioSMART 4 (2): 18-22.

Kitao, S., Ariga, T., Matsudo, T. and Sekine, H. 1993. The Syntheses of Catechin Glucosides by Transglicosylation with Leuconostoc Mesenteroides Sucrose Phosphorylase. Biosci. Biotech. Biochem. 57: 2010-2015.

Klein, K.O. 1998. Isoflavones, Soy-based Infant Formulas, and Relevante to Endocrine Fungtion. AC dupont Hospital for Children Delaware, USA.

Kometani, T., Terada, Y., Nishimura, T., Takii, H. and Okada, S. 1994. Transglicosylation to Hesperidin by Cyclodextrin Glucanotransferase from an Alkalophilic Bacillus species in Alkaline $\mathrm{pH}$ and Properties of Hesperidin Glycosides. Biosci. Biotech. Biochem. 58: 1990-1994.

Lehninger, A.L. 1994. Dasar-Dasar Biokimia. Terjemahan Maggy Thenawidjaya. Penerbit Erlangga, Jakarta.
Mulya, A. 1999. Pengaruh Waktu terhadap Oksidasi LDL dan Kemampuan Antioksidasi Genistein. Skripsi Jurusan Kimia FMIPA Institut Pertanian Bogor, Bogor.

Nilsson, K.G.I. 1988. Enzymatic Synthesis of Oligosacarides. Tibtech. 6: 256-264.

Sulistyo, J. dan Soeka, Y.S. 1999. Bioproses Enzimatik dan Uji Hayati Polifenol Glikosida sebagai Senyawa Antimikroba dan Antimelanogenesis, hlm.227-235. Pros. Sem. Nas. Kimia Bahan Alam. UI-UNESCO, Indonesia.

Sulistyo, J., Soeka, Y.S. dan Karim, A.K. 1998. Sintesis Polifenol $\alpha$-Glukosida oleh CGT-ase secara Transglikosilasi. Biol. Indo. 2:150-161.

Sulistyo, J., Dinoto, A. and Nakahara, K. 2000. Enzymatic Synthesis of Polyphenol Glycosides from Indonesian Tempeh Waste Materials. Proc. The Third ISPUC. JISTEC. p. 529-530.

Suradikusumah, E. 1989. Kimia Tumbuhan. Departemen Pendidikan dan Kebudayaan Dirjen Pendidikan Tinggi PAU-Ilmu Hayat. Institut Pertanian Bogor, Bogor.

Tsuzuki. 1998. The Annual Meeting of the Japanese Society of Nutrititional and Food Science. Kikoman Corporation, Japan.

Uraguchi, K. and Yamazaki, M. 1978. Toxicology Biochemistry and Phathology of Mycotoxins. A. Halsted Press Book, Tokyo. 